University of Nebraska - Lincoln

DigitalCommons@University of Nebraska - Lincoln

USDA National Wildlife Research Center - Staff Publications
U.S. Department of Agriculture: Animal and Plant Health Inspection Service

April 1998

\title{
Cattle guards reduce white-tailed deer crossings through fence openings
}

\author{
J. L. Belant \\ United States Department of Agriculture, National Wildlife Research Center \\ T. W. Seamans \\ USDA/APHIS/WS National Wildlife Research Center, thomas.w.seamans@aphis.usda.gov \\ C.P. Dwyer \\ United States Department of Agriculture, National Wildlife Research Center
}

Follow this and additional works at: https://digitalcommons.unl.edu/icwdm_usdanwrc

Part of the Environmental Sciences Commons

Belant, J. L.; Seamans, T. W.; and Dwyer, C.P., "Cattle guards reduce white-tailed deer crossings through fence openings" (1998). USDA National Wildlife Research Center - Staff Publications. 618.

https://digitalcommons.unl.edu/icwdm_usdanwrc/618

This Article is brought to you for free and open access by the U.S. Department of Agriculture: Animal and Plant Health Inspection Service at DigitalCommons@University of Nebraska - Lincoln. It has been accepted for inclusion in USDA National Wildlife Research Center - Staff Publications by an authorized administrator of DigitalCommons@University of Nebraska - Lincoln. 


\section{Cattle guards reduce white-tailed deer crossings through fence openings}

(Keywords: cattle guards, exclusion device, Odocoileus virginianus, white-tailed deer)

J. L. BELANT†, T. W. SEAMANS and C. P. DWYER:

United States Department of Agriculture, National Wildlife Research Center, 6100 Columbus Avenue, Sandusky, OH 44870, USA

\begin{abstract}
In response to increased white-tailed deer (Odocoileus virginianu\$ encroachment on airports, we evaluated the effectiveness of cattle guards as deer exclusion devices. We conducted three experiments in a 2200 ha fenced facility in northern Ohio with high $\left(91 / \mathrm{km}^{2}\right)$ deer densities during $1994-1995$. In each experiment, we monitored deer crossings at two or three cattle guards $(4.6[\mathrm{~L}] \times 3[\mathrm{~W}] \times 0.5$ or $1.0[\mathrm{D}] \mathrm{m})$ constructed at fence openings for 2 weeks pre- and postinstallation. For each experiment, the mean daily number of deer crossings after installation of cattle guards was reduced $(P<0.01)$ by $\geqslant 88 \%$ compared with respective crossing rates during pretreatment. Reduction in deer crossings using cattle guards with 0.5 or $1.0 \mathrm{~m}$ deep excavations were similar $(95-96 \%$ vs $98 \%)$ overall. Cattle guards at permanent openings used for vehicular traffic appear a viable technique to reduce deer movements into fenced airports and other facilities where reductions in deer intrusions are desired.
\end{abstract}

\section{Introduction}

Deer at airports are a threat to aviation safety, as they are involved in $65 \%$ of aircraft-mammal strikes (Frankenfield et al., 1994). Increasing deer populations in many urban areas have resulted in the increased encroachment by deer on airports (Bashore and Bellis, 1982). Airports frequently contain large expanses of grasses and forbs (dicotyledonous herbaceous plants) that can provide high-quality forage for deer. Many airports have installed perimeter fences to exclude deer, but deer often continue to enter these facilities through access points that remain open for emergency or service vehicles.

Cattle guards are widely used to prevent hoofed livestock from traversing between fenced areas through permanent openings maintained for vehicular access (Hoy, 1982). However, there has been little consideration of, or research on, their use at airports to exclude deer (but see Bashore and Bellis, 1982). If deer can be excluded by cattle guards, these devices could provide a safe and humane method for solving deer problems at some airports. Therefore, our objective was to evaluate the effectiveness of cattle guards in preventing whitetailed deer (Odocoileus virginianus) from entering exclosures through permanent openings.

†Present address: US National Park Service, Denali National Park and Preserve, PO Box 9, Denali Park, AK 99755, USA.

$\ddagger$ Present address: Crane Creek Wildlife Experiment Station, Ohio Department of Natural Resources, 13229 W. SR 2, Oak Harbor, OH 43449, USA.

\section{Materials and methods}

The study was conducted during $1994-1995$ at the 2200 ha National Aeronautic and Space Administration Plum Brook Station (PBS), Erie County, Ohio, which is enclosed by a $2.4 \mathrm{~m}$ high chain-link fence with barbed-wire outriggers. During this study, PBS contained an estimated 2000 white-tailed deer $\left(91 / \mathrm{km}^{2}\right)$ (E. Cleary, United States Department of Agriculture, personal communication). An airport with runways is maintained in a 700 ha area of PBS that is separated from the remainder of PBS by a $1.7 \mathrm{~km}$ long chain-link fence $(2.4 \mathrm{~m}$ high). This fence served as the test site for evaluating cattle guards.

Three $3.1 \mathrm{~m}$ wide openings spaced $0.6 \mathrm{~km}$ apart along the $1.7 \mathrm{~km}$ fence were created during summer 1994. An infrared monitoring device (TrailMaster ${ }^{R}$, Goodson and Assoc., Inc., Lenexa, Kans.) was used to count the number of deer crossings at each site. Infrared monitors were checked at least twice weekly. We limited the number of intrusions recorded by the infrared monitor to observations $\geqslant 2 \mathrm{~min}$ apart. This interval was selected because multiple events; attributed to activation of the monitoring units by environmental factors (e.g. insolation, precipitation) or the same animal attempting to cross cattle guards, were infrequently recorded over short $(<2 \mathrm{~min})$ time periods.

An excavation $(4.6[\mathrm{~L}] \times 3[\mathrm{~W}] \times 0.5[\mathrm{D}] \mathrm{m})$ was then created at each opening; deer were allowed to use these excavations for $\geqslant 1$ month prior to each experiment. Because deer were probably able to contact the bottom of these $0.5 \mathrm{~m}$ deep excavations when cattle guards were installed, we increased the depth of excavations to $1.0 \mathrm{~m}$ during the final experiment to determine if this greater depth would further reduce the number of crossings.

Simulated cattle guards were constructed following United States Department of Agriculture (1960) guidelines by building $4.6 \times 3 \mathrm{~m}$ wooden frames using $5 \times 15 \mathrm{~cm}$ lumber (figure 1). Twenty-two $7.6 \mathrm{~cm}$ diameter $\times 3 \mathrm{~m}$ PVC pipes were spaced evenly at $12.7 \mathrm{~cm}$ intervals across each wood frame, parallel to the fence opening and level with the ground surface. To prevent entanglement and potential injuries to deer while attempting to cross cattle guards, pipes were not secured to the wood frame. The existing $2.4 \mathrm{~m}$ high chain-link fence was extended along each side of the cattle guard to prevent deer from crossing along the side. Track plots of soil were established in excavated and approach areas as a second means to monitor deer use of cattle guards. 
Table 1. Mean daily number of deer crossings through $3.1 \mathrm{~m}$ wide fence openings before and after simulated cattle guards were installed at National Aeronautic and Space Administration Plum Brook Station, Erie County, Ohio, 1994 - 1995

\begin{tabular}{|c|c|c|c|c|c|c|}
\hline \multirow[b]{2}{*}{ Experiment (dates) } & \multirow{3}{*}{$\frac{\text { Cattle guard }}{\text { A }}$} & \multicolumn{4}{|c|}{ Number of deer crossings/day } & \multirow{3}{*}{$\frac{\% \text { reduction }}{98}$} \\
\hline & & \multicolumn{2}{|c|}{ Pretreatment ( $n=14$ days) } & \multicolumn{2}{|c|}{ Treatment ( $n=14$ days) } & \\
\hline \multirow[t]{3}{*}{1 (22 Oct- 18 Nov 1994) } & & 14.2 & 7.8 & 0.4 & 0.5 & \\
\hline & B & 15.1 & 5.4 & 0.8 & 1.8 & 95 \\
\hline & & 14.6 & 6.6 & 0.6 & 1.3 & 96 \\
\hline \multirow[t]{4}{*}{2 (25 June - 10 July 1995) } & A & 7.4 & 4.1 & 0.9 & 1.0 & 88 \\
\hline & B & 11.6 & 8.0 & 0.4 & 0.6 & 96 \\
\hline & $\mathrm{C}$ & 10.7 & 7.4 & 0.1 & 0.4 & 99 \\
\hline & & 9.9 & 6.8 & 0.5 & 0.8 & 95 \\
\hline \multirow[t]{3}{*}{3 (22 Sep-20 Oct 1995) } & B & 4.4 & 3.1 & 0.2 & 0.4 & 95 \\
\hline & $\mathrm{C}$ & 4.5 & 3.1 & 0.0 & 0.0 & 100 \\
\hline & & 4.4 & 3.0 & 0.1 & 0.3 & 98 \\
\hline
\end{tabular}

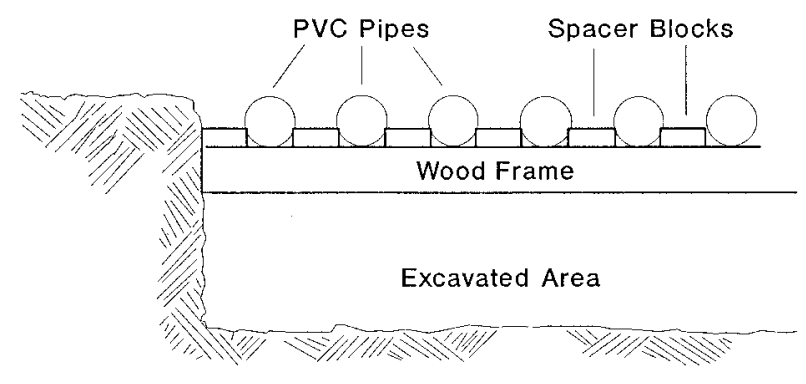

Figure 1. Profile of simulated cattle guard showing $7.6 \mathrm{~cm}$ diameter PVC pipes placed parallel between spacer blocks on wood frame over excavation.

We conducted Experiments 1 and 2 with cattle guards installed over 0.5 m excavations (22 Oct. - 18 Nov. 1994 and 25 June - 10 July 1995, respectively) and Experiment 3 (22 Sept. 20 Oct. 1995) with cattle guards installed over $1.0 \mathrm{~m}$ excavations. Because of equipment failure at one site, only two cattle guards were evaluated during Experiment 1. We also evaluated only two cattle guards during Experiment 3 because standing water (about $0.5 \mathrm{~m}$ depth) in the excavation at one site precluded deer use of the opening during pretreatment.

We determined the effectiveness of cattle guards by comparing the mean daily number of deer crossings during pretreatment and treatment. Differences in deer movements during pretreatment and treatment for each cattle guard during each experiment were analysed using Wilcoxon Rank Sum tests (Zar, 1984; SAS Inst., Inc., 1988). To assess whether the number of deer crossings increased during the treatment period, we similarly compared the number of crossings between week 1 and week 2 post-installation.

\section{Results}

During Experiment 1, the overall mean daily number of deer crossings $( \pm S D)$ was reduced $96 \%$ (14.6 \pm 6.6 pretreatment; $0.6 \pm 1.3$ treatment) after installation of cattle guards over the 0.5 m excavations (table 1). Reductions (Sites $A$ and $B: Z=4.15$ and 4.57 , respectively, $P<0.01$ ) in the number of crossings (95 and $98 \%$ ) were comparable between sites. Similarly, for Experiment 2, the overall mean daily number of deer crossings was reduced $95 \%$ (9.9 \pm 6.8 pretreatment; $0.5 \pm 0.8$ treatment). Reductions (Sites $A-C$ : $Z=4.33,4.54$, and 4.67, respectively, $P<0.01$ ) in the number of crossings among sites ranged from 88 to $99 \%$. During Experiment 3, the mean daily number of deer crossings after cattle guards were installed over the $1.0 \mathrm{~m}$ excavations was reduced $98 \%(4.4 \pm 3.0$ pretreatment; $0.1 \pm 0.3$ treatment) overall relative to pretreatment mean daily crossing rates. Reductions (Sites $B$ and $C: Z=1.88$ and 4.57, respectively, $P<0.01$ ) of $95 \%$ and $100 \%$ were recorded at individual sites. Overall, the mean daily number of crossings recorded during pretreatment for Experiment 3 was $\geqslant 59 \%$ less than the number of crossings recorded during pretreatment for Experiments 1 and 2 .

During each of the three experiments, numerous tracks in approach areas indicated that deer often approached cattle guards but did not cross. Tracks and displaced pipes centrally located in cattle guards indicated that deer occasionally had attempted to leap across cattle guards.

There was a decrease $(Z=2.18, P=0.03)$ in the number of deer crossings from week 1 to week 2 treatment at one cattle guard during Experiment 3. There were no differences $(Z=0.11-1.79, P \geqslant 0.07)$ in the number of crossings between week 1 and week 2 treatment for remaining cattle guards during the experiments.

\section{Discussion}

Cattle guards appear to be an effective method of reducing deer crossings through fence openings. Although the number of deer travelling through openings was reduced $\geqslant 95 \%$ overall, deer apparently remained able to occasionally cross. However, it is possible that single events recorded by the infrared monitors could have been caused by environmental factors other than deer. Thus, the reductions in the number of deer crossings reported here may be conservative.

The number of deer crossings during pretreatment was similar for Experiments 1 and 2, suggesting that deer were excluded by cattle guards and not the excavations. However, increasing the depth of the excavations under the cattle guards from 0.5 to 1.0 may have influenced deer use of these sites and caused the reduction of deer crossings recorded before installation of cattle guards during Experiment 3. Also, rainfall prior to the pretreatment period of Experiment 3 which resulted 
in 2-5 cm of water in the excavations may have influenced deer use of the sites.

Although increasing the depth of excavations under cattle guards did not appear to enhance exclusion of deer, it may simplify maintenance. For example, cattle guards placed in areas with moderate to high snowfall may become filled with compacted snow, allowing deer to cross unencumbered. Increasing the depth of excavations or constructing cattle guards in removable sections to facilitate snow removal could reduce this potential problem. In addition, we recommend installing fences or other suitable barriers adjacent to $(\leqslant 0.1 \mathrm{~m})$ and along the entire length of cattle guards to maximize their effectiveness.

We emphasize that cattle guards used in this study were simulated; actual caltle guards should be constructed following United States Department of Agriculture (1960) guidelines. Cattle guards at permanent openings used for vehicular traffic appear to be a viable technique to exclude deer from fenced airports and other facilities where deer exclusion is desired.

\section{Acknowledgements}

A. L. Bower, PBS, granted permission to use study sites; J. Knoll made excavations for the cattle guards. E. C. Clearly provided the initial idea for the cattle guard evaluation and, with
R. A. Dolbeer, provided field assistance. R. A. Dolbeer also provided valuable suggestions for manuscript improvement. Sponsorship and funds for this research were provided by the Federal Aviation Administration (FAA), Office of Aiports Safety and Standards, Washington, DC, and Airports Division, Airport Technology Branch, FAA Technical Centre, Atlantic City International Airport, New Jersey.

\section{References}

BASHORE, T. L. and BELLIS, E. D., 1982. Deer on Pennsylvania airfields: problems and means of control. Wildife Society Bulletin, 10, 386-388.

FRANKENFIELD, D. L., LEBOEUF, E., FLOYD. J., LANGE, W. R. and BAKER, S. P., 1994. Animal Ambush at the Aiport: Wildife Hazards in U.S. Aviation, 1983 - 1993 (Baltimore, Maryland: Special Report Johns Hopkins University, School Public Health, Center for Injury Research and Policy), $17 \mathrm{pp}$.

HOY, J. F., 1982. The Cattle Guard: its History and Lore (Lawrence: University of Kansas Press), 233 pp.

SAS INSTITUTE., 1988. SASISTAT User's Guide. Version 6.03 (Cary, North Carolina: SAS Institute, Inc.), $1028 \mathrm{pp}$.

U.S. DEPARTMENT OF AGRICULTURE, 1960. Cattie Guards (Washington, DC: United States Department of Agriculture Miscellaneous Publication 831), Deer exclusion device 2 pp.

ZAR, J. H., 1984. Biostatistical Analysis, 2nd edition (Englewood Cliffs, New Jersey: Prentice Hall), 718 pp. 